\title{
Traumatic brain injury - modeling neuropsychiatric symptoms in rodents
}

\section{Oz Malkesman, Laura B. Tucker, Jessica OzI and Joseph T. McCabe*}

Department of Anatomy, Physiology and Genetics, Pre-Clinical Models for TBI and Behavioral Assessments Core, The Center for Neuroscience and Regenerative Medicine, Uniformed Services University of the Health Sciences (USUHS), Bethesda, MD, USA

\section{Edited by:}

Yun Chen, US Army Medical Research Institute of Chemical Defense, USA

\section{Reviewed by:}

Sonia Villapol, Uniformed Services University, USA

Jinhui Chen, Indiana University

School of Medicine, USA

*Correspondence:

Joseph T. McCabe, Department of

Anatomy, Physiology and Genetics,

Pre-Clinical Models for TBI and

Behavioral Assessments Core, The Center for Neuroscience and

Regenerative Medicine, Uniformed Services University of the Health

Sciences (USUHS), 4301 Jones

Bridge Road, Bethesda, MD

20814-4799, USA

e-mail: joseph.mccabe@usuhs.edu
Each year in the US, 1.5 million people sustain a traumatic brain injury (TBI). Victims of TBI can suffer from chronic post-TBI symptoms, such as sensory and motor deficits, cognitive impairments including problems with memory, learning, and attention, and neuropsychiatric symptoms such as depression, anxiety, irritability, aggression, and suicidal rumination. Although partially associated with the site and severity of injury, the biological mechanisms associated with many of these symptoms - and why some patients experience differing assortments of persistent maladies - are largely unknown. The use of animal models is a promising strategy for elucidation of the mechanisms of impairment and treatment, and learning, memory, sensory, and motor tests have widespread utility in rodent models of TBI and psychopharmacology. Comparatively, behavioral tests for the evaluation of neuropsychiatric symptomatology are rarely employed in animal models of TBI and, as determined in this review, the results have been inconsistent. Animal behavioral studies contribute to the understanding of the biological mechanisms by which TBI is associated with neurobehavioral symptoms and offer a powerful means for pre-clinical treatment validation. Therefore, further exploration of the utility of animal behavioral tests for the study of injury mechanisms and therapeutic strategies for the alleviation of emotional symptoms are relevant and essential.

\section{Keywords: traumatic brain injury, animal models, depression, anxiety, irritability, aggression, suicide}

\section{INTRODUCTION}

Traumatic brain injury (TBI) is associated with a range of post injury complaints, and currently there are no fully effective therapies for most of these symptoms (1-4). The lack of effective therapies, the vast number of affected individuals worldwide, the loss of earning power, the cost for care, and the rehabilitative needs of patients affirms that research is essential for expanding our understanding of the pathophysiology of TBI and for developing effective treatments.

A promising strategy for the identification of the biological mechanisms underlying TBI symptomatology and facilitating the search for effective therapies is the use of animal models. Previous reviews have well described the fact that the complexity of TBI makes it difficult for a single animal model to reproduce the entire range of symptoms that occur post-TBI (5-9). Yet, animal models can mimic some of the human conditions resulting from forceful collision, non-impact acceleration, blast wave exposure, and polytraumatic events [for review, see Ref. (6)]. There are several previous, excellent reviews addressing animal models of TBI and behavior (10-13). However, the focus was primarily on cognitive and/or motor symptoms, with less attention to the neuropsychiatric symptoms frequently identified in post-TBI patients. This review focuses on the status of behavioral tests used in rodents to model depression, anxiety, irritability, aggression, and suicidal behaviors associated with TBI.

\section{HUMAN TBI: THE EXTENT OF THE PROBLEM}

Traumatic brain injury is a general term for a spectrum of focal and diffuse cerebral insults that result from sudden impact, changes in inertial forces, penetrating wounds, hypoxic and toxic metabolic insults, and vascular injuries of the cerebrum. Analysis of the causes and consequences of traumatic brain injuries is traditionally seen as occurring in two phases: (1) primary injury - arising from the aforementioned changes and (2) secondary injury - the biochemical and physiological brain changes caused by the primary injury, including excitotoxicity and energy failure, ischemia, cell death, edema, delayed axonal injury, and inflammation.

In 1999, the Centers for Disease Control and Prevention recognized the medical, economic, personal, and domestic consequences of TBI (14). Termed "a silent epidemic," each year in the US, over 1.5 million people sustain a TBI (15). About $70-90 \%$ of these injuries are described as mild (16), although the percentage may be greater than this estimate with consideration that some victims do not receive treatment. Principally resulting from vehicular and home accidents or sports injuries (17), there has been continued discussion of what constitutes "mild TBI," where complaints may include headaches, dizziness, mental "cloudiness," a brief loss of consciousness, and post-traumatic amnesia [see Ref. (18) for further discussion of definitions]. TBI is also one of the most common injuries among US military and civilian personnel, where in the last decade an estimated $15-20 \%$ of soldiers experienced mild TBI during deployment mainly due to explosives and 
blast injuries (19), and almost $80 \%$ of these insults were diagnosed as mild (20).

For milder cases, the complaints usually diminish with time. Bruns and Jagoda (21), for example, cite earlier work that $>58 \%$ of mild TBI victims manifest symptoms at 1 month after injury (22), but that the percentage declines to $15 \%$ by 1 year after injury (23). The latter, however, even for mild TBI cases, is a "nontrivial minority" (19). These cognitive, emotional, behavioral, and somatic problems can be debilitating and a substantial source of stress to TBI survivors and their families (24).

While there is less evidence of such long-term effects from mild injuries, neurodegenerative disorders have been associated with moderate and severe TBI $(25,26)$. For example, Bazarian and colleagues reviewed 75 reports regarding the long-term effects (defined as present at least 6 months post injury) from TBI (25). Dementia of the Alzheimer's type, Parkinson's disease, and endocrine disorders were associated with moderate and severe TBI. Post-traumatic seizures were also associated with TBI, especially if the injury was a penetrating event. For mild TBI, this group reported previous work indicating a diversity of complaints including, memory impairment, dizziness, headache, difficulties with attention, sleep disturbances, depression, anxiety symptoms, reduced stress tolerance, apathy, a lack of spontaneity, emotional excitability, and irritability (25).

Recent publications have underlined the serious, long-term effects of repeated "mild" trauma. Although much work needs to be done to define many of the specific contributors to the insidious effect from head impacts, there is evidence that repeated injuries from sport activities and possibly blast exposures, seemingly inconsequential at the time, are antecedent conditions for mood and cognitive impairments. In addition to a higher incidence of Alzheimer disease, it has been recognized that chronic traumatic encephalopathy is associated with repetitive "mild" impacts $(27,28)$.

Although treatment and rehabilitation of TBI has primarily focused on sensory, motor, and cognitive symptoms, co-morbid neuropsychiatric disorders (see Table 1 for a summary of the core features) that give rise to emotional and behavioral difficulties significantly impair the quality of the lives of patients and even can lead to suicide behavior $(29,30)$. To provide context for how behavioral testing can be employed to study post-TBI-like symptoms in pre-clinical rodent models, the clinical phenotypes are briefly reviewed. Rodent behavioral tests purportedly related to each of the aforementioned neuropsychiatric dimensions are then described, and the test's utility in TBI research is reviewed. In general, results from the evaluation of neuropsychiatric symptoms in pre-clinical models have been limited. It is proposed that further validation is needed to relate pre-clinical models with TBI-associated neuropsychological systems.

\section{DEPRESSION SYMPTOMS}

The most common psychiatric complaint in patients with mild TBI is depression $(19,31)$. The reported prevalence of depression varies between studies, and ranges from 10 to $77 \%$ (32-34). Several factors contribute to the reported variability of post-TBI depression, including differences in diagnostic criteria, severity of the TBI, the time after TBI when the diagnosis is made, and diversity in patient populations (33). Rates of depression in patients with TBI are highest in the first year after the injury is sustained (35), but the risk for the appearance of depression remains elevated even decades after injury (36).

The primary symptoms of depression following TBI include episodes of sadness, negativism, loss of pleasure, feelings of hopelessness, suicidal thoughts, and sometimes psychosis (37). Victims often experience increased psychological distress and poor psychosocial status (38). In addition, depression is associated with a greater number and perceived severity of a variety of so-called post-concussive symptoms including, headache and dizziness complaints, irritability and memory problems, and sensory system-related complaints of irritability with lights and noises $(39,40)$.

\section{ANXIETY SYMPTOMS}

Anxiety disorders develop in $10-70 \%$ of patients with a mild TBI $(19,37,41)$. As with depression, the wide range of reported prevalence is due to the nature of data collection, the severity of the brain injury, and confounding effects of demographic factors. Silver and colleagues (29) found (after adjusting for the potentially confounding effects of demographic factors, quality of life, and alcohol abuse) that individuals who experienced TBI reported a higher prevalence of panic disorder and phobic disorder compared to the control group. Fann and colleagues (39) found that $24 \%$ of outpatients with TBI had generalized anxiety disorder, while Jorge and colleagues (35) reported that $11 \%$ of the patients with TBI developed generalized anxiety disorder in addition to major depression. The core features of anxiety following TBI include

Table 1 | Traumatic brain injury-related neuropsychiatric symptoms.

\begin{tabular}{|c|c|c|}
\hline Post-TBI symptoms & Prevalence (\%) & Core features \\
\hline Depression & $10-77$ & Episodes of sadness, loss of pleasure, negativism, feeling of hopelessness, and suicide thoughts \\
\hline Anxiety & $10-70$ & $\begin{array}{l}\text { Feeling of apprehension or dread with or without autonomic signs and symptoms. Anxiety with feelings of } \\
\text { re-experiencing trauma, avoidant behavior, emotional numbing }\end{array}$ \\
\hline Irritability & $15-37$ & Reduced control over temper which usually results in irascible verbal or behavioral outbursts \\
\hline Aggression & $11-34$ & $\begin{array}{l}\text { Destructive behaviors toward individuals or property; behaviors, attitudes, or moods that others perceive as } \\
\text { threatening; and/or purposeful attempts to disrupt rehabilitation and discharge from hospital }\end{array}$ \\
\hline Suicidality & $1-17$ & High rates of critical indicator of suicide risk, including: hopelessness, suicide ideation, and suicide attempts \\
\hline
\end{tabular}


feelings of apprehension or dread with or without autonomic signs and symptoms. Post-traumatic stress disorder (PTSD) is also commonly experienced by victims of TBI, and is described as anxiety with feelings of re-experiencing trauma, avoidant behavior, emotional numbing, and hypervigilance (37).

\section{IRRITABILITY}

A prevalent post-TBI neuropsychiatric symptom is irritability (4244). Irritability can be defined as "a feeling state characterized by reduced control over temper which usually results in irascible verbal or behavioral outbursts, although the mood may be present without observed manifestation" (45). One study found that more than $37 \%$ of the patients between the ages 18 and 65 suffered from irritability post-TBI (42), and another study indicated irritability is one of the most frequently reported symptoms by TBI patients, and that this symptom remains notable even 10 years after injury (46). Furthermore, several studies of irritability indicate it as one of the major risk factors for suicidality (47), and has a strong association with suicidal ideation and suicide attempts (48, 49). Irritability can have a significant toll on the wellbeing of the patient and their family; it often dwells in the family system and has a life-changing impact on martial relationships (50).

\section{AGGRESSION}

Within the Hostility Inventory developed by Buss and Durkee (51), irritability was recognized as one of the major components of an "aggression" factor. Behavioral responses to irritable states include verbal and physical aggression that contribute significantly to social and family difficulties experienced by patients with TBI (52). Broadly defined, aggression in humans is "destructive behaviors toward individuals or property; behaviors, attitudes, or moods that others perceive as threatening; and/or purposeful attempts to disrupt rehabilitation and discharge from hospital" $(53,54)$. There is a wide range in the current estimates of the presence of aggression in TBI patients and in a critical review of the literature, Kim and colleagues (55) concluded that these estimations are limited by a lack of a rigorous definition of the term "aggression," as well as inconsistent methodology for identifying aggressive behaviors. In addition, family-reported aggression tends to be higher than self-reported aggression $(44,56)$, contributing to variability in summaries of prevalence.

Nevertheless, there is agreement that TBI increases the risk of aggressive behavior and some findings remain consistent in studies of post-TBI aggression. Aggressive behavior shows a high association with mood disorders and substance abuse $(57,58)$ and other co-morbid problems that were present before the injury (57). A prior-injury history of aggression was also highly correlated with post injury aggressive behaviors $(52,54)$. Of some fortune, aggressive behaviors displayed by brain-injured patients were most often characterized by expressions of anger and threats of violence rather than actual physical violence (58). In addition to the challenges aggressive reactivity has for the patient, family members, and caregivers, aggression may also increase the risk of co-morbid psychiatric conditions and/or suicide (59).

\section{SUICIDE}

Suicidal ideation and suicide attempts post-TBI have been reported in numerous studies (60-63). One report indicates the rate of suicide in TBI patients is 2.7-4 times higher than of the general population, matched for sex and age (64). In addition, continuous military operations in Afghanistan and Iraq in the last decade have been found to be associated with increases in mild TBIs and suicides among US military personal (65). From the clinical picture, TBI patients have high rates of critical indicators of suicide risk, including hopelessness (35\%), suicide ideation (23\%), and suicide attempts (18\%) (63).

Several studies have attempted to phenotype the association between TBI and suicide behavior, and one of the findings was the correlation between the severity of the injury and suicide behavior. A more severe injury is associated with a greater chance for suicide behavior (66-68). However, no correlation was found between suicide behavior and the injury localization (66). In addition, it was found that the risk of suicide following TBI is unceasing; even 15 years after the injury (64). However, it is important to mention that although studies frequently report suicidality is a common neuropsychological response to TBI, several studies in non-military populations did not find increased suicide risk among TBI patients $(69,70)$. Therefore, further exploration of the association between TBI and suicide behavior is warranted.

\section{POST INJURY SYMPTOMS IN ANIMAL MODELS OF TB|}

Primarily in the field of psychopharmacology, core clinical features of psychiatric diagnoses in humans have been modeled in animals. Table 2 lists the symptoms of human diagnoses and corresponding animal tests that allow for measurement of that specific symptom in laboratory animals. The data collected for this review is limited due to difficulty in determination of publications that did not include the test name in the title, key words, or abstract. However, this is intended as an overview of emotional systems testing in rodents after TBI.

\section{DEPRESSION}

The two clinical hallmarks of a major depressive disorder are anhedonia and behavioral despair (71). Anhedonia is a phenomenon in which there is a loss of interest in pleasure derived from typically enjoyable experiences or activities. Behavioral despair is manifested in rodents where there is a significant decline in the animal's effort to avoid or escape aversive situations (72). Specific behavioral tests allow these clinical hallmarks to be evaluated in laboratory animals.

\section{Sucrose/saccharin preference}

The sweet taste of sugar is a potent motivator both in humans and rodents (73). An often-employed, non-operant method for assessing hedonic sensitivity in rodents is the measurement of preference for consuming sweetened fluids (sucrose/saccharin) over water (74-76). Indeed, rodents will not only consume a freely available sweet solution, they will perform a variety of tasks to obtain rewarding solutions: press levers, run down an alley, etc. In general, rodents will work harder as the concentration of the sweet solute is increased (73).

Rodents normally exhibit very high preferences for the sweeter solution, but this preference diminishes after exposure to chronic mild stress or when they exhibit other depression-like symptoms. Willner and colleagues (74) proposed that reduced consumption 
Table 2 | Summary of human emotional systems and animal tests related to post-TBI symptoms in humans.

\begin{tabular}{|c|c|c|c|c|c|c|}
\hline $\begin{array}{l}\text { Emotional } \\
\text { system }\end{array}$ & $\begin{array}{l}\text { Models of } \\
\text { human } \\
\text { symptom }\end{array}$ & Rodent test & Test parameter & $\begin{array}{l}\text { TBI effect on } \\
\text { animal } \\
\text { performance }\end{array}$ & $\begin{array}{l}\text { Number of } \\
\text { hours/days } \\
\text { TBI effect lasted }\end{array}$ & Reference \\
\hline \multirow{5}{*}{$\begin{array}{l}\text { Depression- } \\
\text { like } \\
\text { symptoms }\end{array}$} & Anhedonia & $\begin{array}{l}\text { Sucrose/saccharin } \\
\text { preference }\end{array}$ & $\begin{array}{l}\text { Preference for consuming } \\
\text { sweetened fluids (sucrose/ }\end{array}$ & Inconclusive & $\begin{array}{l}\text { 7-30 days post } \\
\text { injury }\end{array}$ & $\begin{array}{l}\text { Jones et al. (79), Cope et } \\
\text { al. (80) }\end{array}$ \\
\hline & & & saccharin) over water & & & \\
\hline & Anhedonia & $\begin{array}{l}\text { Female urine-sniffing } \\
\text { test }\end{array}$ & $\begin{array}{l}\text { Preference for sniffing } \\
\text { estrus female urine odor } \\
\text { over water }\end{array}$ & No studies & $\begin{array}{l}\text { Not applicable } \\
\text { (N/A) }\end{array}$ & N/A \\
\hline & $\begin{array}{l}\text { Despair } \\
\text { behavior }\end{array}$ & Porsolt swim test & $\begin{array}{l}\text { Measurement of swimming } \\
\text { activity during } 6 \text { min of the } \\
\text { test }\end{array}$ & Inconclusive & $\begin{array}{l}\text { 7-90 days post } \\
\text { injury }\end{array}$ & $\begin{array}{l}\text { Milman et al. (81), Taylor et } \\
\text { al. (82), Tweedie et al. (83), } \\
\text { Jones et al. (79), } \\
\text { Schwarzbold et al. (84), } \\
\text { Wang et al. (85), } \\
\text { Washington et al. (86), } \\
\text { Shultz et al. (87), Kimbler } \\
\text { et al. (88) }\end{array}$ \\
\hline & $\begin{array}{l}\text { Despair } \\
\text { behavior }\end{array}$ & Tail suspension test & $\begin{array}{l}\text { Measurement of struggling } \\
\text { behavior during } 6 \text { min of the } \\
\text { test, while the mouse is } \\
\text { suspended by its tail }\end{array}$ & No effect & $\begin{array}{l}7 \text { and } 30 \text { days } \\
\text { post injury }\end{array}$ & $\begin{array}{l}\text { Ando et al. (89), Vuckovic } \\
\text { et al. (90) }\end{array}$ \\
\hline \multirow[t]{4}{*}{$\begin{array}{l}\text { Anxiety-like } \\
\text { symptoms }\end{array}$} & Anxiety & Elevated-plus maze & $\begin{array}{l}\text { Measuring the time spent in } \\
\text { the open arm of the arena } \\
\text { vs. the closed arms }\end{array}$ & Inconclusive & $\begin{array}{l}\text { 5-14 days post } \\
\text { injury }\end{array}$ & $\begin{array}{l}\text { Cutler et al. (91), Pandey et } \\
\text { al. (92), Schwarzbold et al. } \\
\text { (84), Shultz et al. (87), } \\
\text { Washington et al. (86) }\end{array}$ \\
\hline & Anxiety & Zero maze & $\begin{array}{l}\text { Measuring the time spent in } \\
\text { the area behind the walls vs. } \\
\text { the open area }\end{array}$ & Inconclusive & $\begin{array}{l}17 \text { days }-7 \text { weeks } \\
\text { post injury }\end{array}$ & $\begin{array}{l}\text { Ajao et al. (93), Siopi et al. } \\
\text { (94), Tucker et al. (95) }\end{array}$ \\
\hline & Anxiety & Light/dark test & $\begin{array}{l}\text { Measuring the time spent in } \\
\text { the dark area of the arena } \\
\text { vs. the lit area }\end{array}$ & $\begin{array}{l}\text { One study; } \\
\text { less time in } \\
\text { light chamber }\end{array}$ & $\begin{array}{l}\sim 1 \text { week post } \\
\text { injury }\end{array}$ & Cope et al. (80) \\
\hline & $\begin{array}{l}\text { Anxiety and } \\
\text { spontaneous } \\
\text { activity }\end{array}$ & Open field & $\begin{array}{l}\text { The total distance traveled is } \\
\text { measured (in } \mathrm{cm} \text { ); In } \\
\text { addition, the relative } \\
\text { amounts of time that a } \\
\text { mouse or rat spends in the } \\
\text { center of the open field area } \\
\text { versus the peripheral region } \\
\text { may also be a valid measure } \\
\text { of anxiety }\end{array}$ & $\begin{array}{l}\text { Inconclusive in } \\
\text { rats; "hyperac- } \\
\text { tivity" in } \\
\text { mice }\end{array}$ & $\begin{array}{l}\text { Increased activity } \\
-24 \text { h-7 days } \\
\text { post injury } \\
\text { Decreased activ- } \\
\text { ity - 10-14 days } \\
\text { Tendency to } \\
\text { spend less time } \\
\text { in the center }\end{array}$ & $\begin{array}{l}\text { O’Connor et al. (96), } \\
\text { Fromm et al. (97), Wagner } \\
\text { et al. (98), Tweedie et al. } \\
\text { (83), Jones et al. (79), } \\
\text { Pandey et al. (92), Wakade } \\
\text { et al. (99), Schwarzbold et } \\
\text { al. (84), Tucker et al. (95), } \\
\text { Kimbler et al. (88), Yu et al. } \\
\text { (100), Budinich et al. (101), } \\
\text { Tucker et al. (102) }\end{array}$ \\
\hline \multirow[t]{2}{*}{$\begin{array}{l}\text { Irritability-like } \\
\text { behavior }\end{array}$} & Irritability & $\begin{array}{l}\text { Resistance to } \\
\text { capture or attempts } \\
\text { to struggle while } \\
\text { being restrained }\end{array}$ & $\begin{array}{l}\text { The extent and duration of } \\
\text { struggling behavior is used } \\
\text { to measure irritability }\end{array}$ & No studies & N/A & $\mathrm{N} / \mathrm{A}$ \\
\hline & & $\begin{array}{l}\text { Responsiveness to } \\
\text { uncomfortable } \\
\text { stimuli }\end{array}$ & Reactivity to the stimuli & & & \\
\hline Aggression & Aggression & $\begin{array}{l}\text { Resident-intruder } \\
\text { test }\end{array}$ & $\begin{array}{l}\text { Measurement of aggressive } \\
\text { behavior: attack bites; tail } \\
\text { rattling; wrestling; chasing } \\
\text { behavior; attack latency; in a } \\
\text { 5-min of the test }\end{array}$ & $\begin{array}{l}\text { One study: } \\
\text { impaired social } \\
\text { behavior }\end{array}$ & $\begin{array}{l}2 \text { and } 4 \text { weeks } \\
\text { post injury }\end{array}$ & Semple et al. (103) \\
\hline
\end{tabular}


of sweet solutions by rats after chronic mild stress is a measure of anhedonia. Interestingly, studies have found that different kinds of stressors had distinctive effects on saccharin consumption in rats. Physical (foot shocks) stress resulted in rats having a reduced preference for saccharin solution, while after emotional stress (presence in the adjacent compartment during foot shock treatment of their cage mate), animals displayed a slight increase in sweet solution preference (77).

A variety of saccharin/sucrose preference tests have been described, but the tasks are fundamentally the same. The animal is presented with two bottles; one bottle contains tap water and the other a sweet solution (saccharin or sucrose; the concentration is determined according to the strain of the animals and the lab protocol, and varies from 0.004 to $0.35 \%$ ). The animals have the opportunity to drink as much of the solution or water as they want during a significant amount of time (at least overnight). The bottles are weighed before they have been introduced to the animals and again at the end of the experiment, and a preference ratio is calculated (consumed sweetened solution $) /($ consumed water + consumed sweetened solution). The preference for sweet solution over water exhibited by the rodent is used as a measure for sensitivity to reward (76). Although the sweet solution preference test is widely used, it has limitations. Forbes and colleagues (78) showed that reduced consumption of sweet solution in stressed rats might result solely from diminished body weight, rather than stress per se, and concluded that sucrose consumption cannot be used as a valid test for hedonic responsiveness. In addition, differences in this test may result from alterations in the gustatory system and appetite by gene manipulation and/or pharmacological treatment, and may not truly indicate a change in the reward-seeking state.

Jones and colleagues (79) have explored the effects of TBI on depressive-like symptoms in rats (lateral fluid-percussion injury model; 23.5 atmosphere pressure pulse directed to the right sensorimotor cortex), and found that there were no significant differences between injured rats and sham controls in the sucrose preference test, 1, 3, and 6 months after the primary injury (79). On the other hand, Cope and colleagues found that TBI rats [controlled cortical impact (CCI) to the frontal cortex; $5 \mathrm{~mm}$ impactor tip, $3 \mathrm{~mm}$ depth, $2.25 \mathrm{~m} / \mathrm{s}$, impact time $500 \mathrm{~ms}$ ] showed a significantly lower preference for saccharin compared to the control sham rats 8 days following injury (80). The number of studies using the sweet solution preference test in rodent models of TBI is, unfortunately, very limited, and therefore it is premature to assert the utility of this measure for TBI rodent models.

\section{Female urine-sniffing test}

The female urine-sniffing test (FUST) is a non-operant method that measures hedonic behavior using a sexual incentive (104). The FUST procedure combines two previous areas of investigation: the olfactory habituation/dishabituation test $(72,105,106)$ and the use of estrus urine or bedding as a sexual incentive $(107,108)$. Studies have shown that estrus female rodent urine extracts elicit specific behavioral displays analogous to those observed in the presence of reward incentive stimuli: increased number of approaches, longer time spent with the stimulus, and shortened approach time to the stimulus [for review, see Ref. (109)].
One hour prior to the test, rodents are habituated to a sterile cotton-tipped applicator inserted into their home cages. After $1 \mathrm{~h}$, the sterile cotton-tipped applicator is removed and each rodent, separately, is transferred to a dimly lit room ( $\sim 3$ lux lighting). The FUST has three phases: (1) water - one exposure ( $3 \mathrm{~min}$ ) to a cotton tip dipped in sterile water, during which sniffing duration is measured; (2) habituation - the rodent cage is transferred from the experiment room to an habituation area for an interval of $45 \mathrm{~min}$ during which no cotton tip is presented; and (3) urine - the animal is transferred back to the experiment room for one exposure ( $3 \mathrm{~min}$ ) to a cotton tip applicator infused with fresh urine collected from females in estrus (of the same strain), and sniffing duration is measured.

The FUST has been validated in several rodent strains (C57BL/6J mice, 129S1/SVImJ mice, and Wistar-Kyoto rats). It has been employed with several pre-clinical experimental paradigms including, learned helplessness ( $\mathrm{LH}$ ) (110), to evaluate the effects of chronic treatment with a selective serotonin-reuptake inhibitor (SSRI) with mice that experienced the LH (104), after single electric shock stress manipulation (104), and with a mouse strain (GluR6KO) that exhibits manic-like symptoms (111). GluR6KO males spent a significantly longer duration sniffing female urine compared to wild-type control mice (104). The FUST is suitable and well validated for measuring hedonic-like behavior in male rodents. However, due to the novelty of the test and the short time of its existence, there are no available data for the effects of TBI in mice or rats.

\section{Porsolt forced swim test}

The forced swim test was developed by Porsolt and colleagues (112) and has become widely used for the study of rodent models of depression or "behavioral despair" (113), response to stress (114), and as a tool for screening antidepressant drugs (112, 115, 116). In the forced swim test, the rodent is placed in a cylinder filled with water with no ability to escape. Typically, animals initially paddle vigorously, but then become relatively immobile (defined as a lack of activity except movements needed to keep the nose above water), and finally may adopt a characteristic vertical floating response. Abel (116) has demonstrated that the vertical immobility response in the forced swim test has a sudden ontogenetic onset, beginning at 21 days of age and quickly stabilizing at 26 days of age.

The procedure may vary for mice and rats. Mice are only immersed once into the cylinder of water for session durations between 4 and 20 min [see Ref. (72) but also, see Ref. (117)], in which a pre-exposure period of $2-5 \mathrm{~min}$ is conducted before the swimming activity is measured. Rats usually are immersed twice in the water cylinder where initially the rats are immersed for $10 \mathrm{~min}$, in which no measurements are taken. Twenty-four hours later, rats are re-immersed for $6 \mathrm{~min}$ and swimming activity is evaluated. However, in some variations of the test, rats are only immersed once and immobility time is recorded during this single session (118-120).

Several studies have found that prepubertal and adult rodents exhibiting depression-like symptoms on several behavioral tests, such as the saccharin preference, also exhibited longer immobility duration in the Porsolt swim test $(114,121-123)$. This increased 
immobility duration can be altered by acute and chronic antidepressant treatment $(121,124,125)$, making the Porsolt forced swim test appropriate for the study of depression-like symptoms in rodents.

Compared to the sweet solution preference tests and the FUST, the swim test has been frequently employed to evaluate rodent performance after TBI. Milman and colleagues (81) found that injured mice showed significantly greater durations of immobility compared to sham controls 7 and 90 days after TBI induced by a weight-drop device (metal weight of $30 \mathrm{~g}$ dropped vertically from 80 -cm height). Taylor and colleagues (82) found that after 8 weeks, rats with TBI induced by CCI (left parietal cortex; $5 \mathrm{~mm}$ diameter impactor tip; 28 psi pressure; $2.75 \mathrm{~m} / \mathrm{s}$ for $250 \mathrm{~ms}$ ) exhibited significantly less swimming behavior compared to the sham controls; also suggesting depression-like symptoms in brain-injured rodents. In addition, clear differences between Imprint Control Region (ICR)-strain mice with a mild TBI (induced by a 30 or $50 \mathrm{~g}$ metal weight dropped from a height of $80 \mathrm{~cm}$ ) and their sham controls were found in a study conducted by Tweedie and colleagues (83), where injured animals spent a longer time immobile when tested 3 days after the injury. Lastly, Washington found CCI (3.5 mm tip, $5.25 \mathrm{~m} / \mathrm{s}$ speed, $0.1 \mathrm{~s}$ dwell time, $1.5-2.5 \mathrm{~mm}$ depth) resulted in a significant increase in immobility time 21 days after injury (86). It is noteworthy to mention that several studies have not found any significant differences in the forced swim test after TBI. Jones and colleagues (79) found no difference in swimming activity between sham controls and rats receiving a TBI to the right sensorimotor cortex (lateral fluid-percussion injury; $\sim 3.5$ atmosphere pressure pulse) 6 months post-TBI. Schwarzbold and colleagues (84), did not find a significant difference between TBI mice and their sham controls, 10 days after the injury induction (weight-drop TBI device, weights varies between 10 and $15 \mathrm{~g}$, with a diameter of $3 \mathrm{~mm}$, and dropped from $120 \mathrm{~cm}$ height on the left parietal region). Wang and co-investigators examined the effect of moderate to severe TBI $(-2.0 \mathrm{~mm} \mathrm{AP}$ and $2.0 \mathrm{~mm}$ ML relative to the bregma suture) of C57BL/ 6 mice, produced by CCI $(2.0 \mathrm{~mm}$ diameter tip; $1.5 \mathrm{~m} / \mathrm{s}$ velocity; $1.25 \mathrm{~mm}$ depth; $155 \mathrm{~ms}$ contact time), and found no difference between brain-injured mice and their sham controls in the forced swim test, 4 weeks post injury (85). Shultz found that only after five injuries by fluid percussion, mice exhibited an increase in immobility score 8 weeks post injury (87). Kimbler observed that, surprisingly, CCI $(4.5 \mathrm{~m} / \mathrm{s}, 20 \mathrm{~ms}$ dwell time, $1 \mathrm{~mm}$ depth, $3 \mathrm{~mm}$ diameter impactor tip) lengthened the latency to immobility $72 \mathrm{~h}$ after injury (88).

The causes for different outcomes from TBI may be related to an oft-cited problem in behavioral research in general; laboratories employ different experimental conditions. Test procedures vary across studies, different strains of animals were used, the time after injury when rodents were evaluated, and the procedure for inflicting TBI and the location of the injury differs across laboratories. Thus, further studies are needed to assess the impact of TBI on performance on the forced swim test.

\section{Tail suspension test}

The tail suspension test has been employed as a measure of depression-like behavior (126). As in the case of the Porsolt swim test, this test is based on the assumption that the emotional state of an animal will influence their efforts to escape an aversive situation, and that the internal states relates to the duration of the escape response (72). In this test, the aversive situation accrues while the mouse is being suspended by the tail, usually for $6 \mathrm{~min}$, while the body suspends in the air facing downward. The duration of struggling to face upward and reach for a solid ground is recorded and compared between mice/strains. Usually, a naïve mouse will struggle for several minutes, but eventually stops moving and remains immobile for the remaining time of the testing session (72).

Few TBI studies have employed the tail suspension test, and further study is needed to determine the effect of TBI on the rodent's behavior in this test. Ando and colleagues (89) found that CCI ( $2 \mathrm{~mm}$ tip; $4.5 \mathrm{~m} / \mathrm{s}$ velocity; $2 \mathrm{~mm}$ depth; $80 \mathrm{~ms}$ contact time) followed by laser treatment reduced immobility time with the tail suspension test 4 weeks after the injury, but the study did not include a sham-treated or naïve control group for comparison. Brain injury by exposure to 1-methyl-4-phenyl-1,2,3,6tetrahydropyridine (MPTP) was found to have no impact upon the performance on the tail suspension test 7 and 30 days post injury compared to the control group (90).

\section{ANXIETY}

Several established procedures for measuring emotional reactivity and anxiety-like symptoms in rodents are based on approachavoidance situations where anxiety alters responses to a conflict inherent in the test setting (72). Here, we will review the most well-known tests.

\section{The elevated-plus maze}

The elevated-plus maze (EPM) is a widely employed measure in anxiety research (127) and an accepted procedure for drug discovery in pharmaceutical companies (128). Rodents have a natural tendency to explore novel environments, but brightly lit, open, elevated areas are perceived by the animal as aversive. The EPM measures the naturalistic conflict between these two features (129).

The maze is usually constructed of Plexiglas in a plus-shaped formation with two dark, enclosed arms and two open welllit arms, elevated $50-100 \mathrm{~cm}$ above a table surface or floor. The dimensions of the arms are usually $30 \mathrm{~cm} \times 5 \mathrm{~cm}$ with a $5 \mathrm{~cm} \times 5 \mathrm{~cm}$ center area, and the walls of the closed arms are $\sim 40 \mathrm{~cm}$ high. A single mouse is placed in the center of the maze for $5 \mathrm{~min}$, and usually tracked with a video camera. The time spent in the three different areas of the maze (closed arms, open arms, and center) and the frequency of visits to these different zones is scored manually or by the use of automated software. Compared to control animals, rodents exhibiting anxiety-like behaviors spend more time in the closed arms of the apparatus than in the open arms. The validity of the test is supported by studies that show performance is sensitive to anxiolytic and anxiogenic compounds: anxiolytic drugs (e.g., benzodiazepines) typically increase the percentage of time spent in the open arms relative to time spent in the open and closed arms together, anxiogenic drugs decrease the amount of time the animals spend in the open arms $(127,130)$.

Schwarzbold and colleagues (84) found that mice 11 days after a TBI induced by a $10-\mathrm{g}$ weight dropped on the left parietal region (from a height of $120 \mathrm{~cm}$ ) exhibited a significant decrease 
in entries into the open arms, and spent less time in the open arms (anxiety-like behavior) compared to sham controls and to mice with TBI induced by 12.5 and $15 \mathrm{~g}$ weight dropped on the same brain region, suggesting that a mild TBI, but not more severe injuries, may result in an elevated anxiety response. On the other hand, Pandey and colleagues (92) found that 14 days after a mild TBI (400 g weight, $10 \mathrm{~mm}$ diameter, dropped from a height of $1 \mathrm{~m}$ on the exposed skull, mid-distance between lambda and bregma sutures), rats exhibited a significant increase in both percentage of open-to-total arm entries and percentage of total time spent in the open arms when compared with rats that underwent sham surgery. Although both of the latter studies have used different species, each claimed to induce "mild" TBI by using the weightdrop procedure. However, the parameters used in these studies are substantially different, and hence may underlie the differences in behavioral results. An estimate of kinetic energy of the weight drop in the Pandey study (92) indicates it may have been three-times greater than what was employed in the Schwarzbold experiment (84).

Cutler and colleagues (91) found no difference in EPM performance between vehicle-repeated injections treated injured rats induced by CCI ( $5 \mathrm{~mm}$ diameter; $1.7 \mathrm{psi} ; 50 \mathrm{~ms} ; 2.25 \mathrm{~m} / \mathrm{s}$ ) and vehicle-repeated injections treated sham controls 5-6 days after injury. But, rats induced by CCI and vehicle treated in silastic capsule implantations spent more time in the open arms compared to vehicle treated in silastic capsule implantations sham controls. In addition, Shultz and colleagues (87) used the EPM and found that repeated fluid-percussion injury (FPI) resulted in a decrease in time spent in the open arms at 24-h and 8 week timepoints postTBI (87). Washington and colleagues (86) measured the duration of mouse exploration in the open arms 21 days after TBI, and found that mild, moderate, and severe TBI animals (induced by CCI) spent a significantly greater amount of time in the open region - hence, showing reduction in anxiety-like behavior and increase in risk-taking-like behavior (86), compared to their controls, with no effect related to the extent of the injury. Thus, the effect of TBI on anxiety-like behavior in the EPM in mice and rats is unclear and further studies are needed.

\section{Zero maze}

Considered a "modification" of the EPM, the zero maze has been used to evaluate anxiety-related behaviors in rodents (131), and in the last year has seen utility in rodent model studies of TBI (93-95). Similar to the EPM, the zero maze is brightly lit, with alternation between dark areas surrounded by walls, and open areas along an elevated circular runway. As opposed to the EPM, the zero maze has no central start box, in which mice often remain for significant periods of time; hence avoiding the ambiguity in scoring arm entries and reducing variability of the data (72).

Ajao and colleagues report that when 17 day-old rats sustained CCI (3-mm diameter impactor, $1.5 \mathrm{~mm}$ depth, $200 \mathrm{~ms}$ duration at $6 \mathrm{~m} / \mathrm{s}$ velocity), they exhibited an increase in time spent in the dark (walled) regions of the maze compared to sham-treated animals 60 days after injury (93). Siopi and colleagues performed weightdrop injuries ( $50 \mathrm{~g}$ weight, dropped from $36 \mathrm{~cm}$ height) on mice and compared their performance to naïve-treated animals (94). Injured mice exhibited no change in the percentage of time or the number of entries into the open portion of the zero maze, but they exhibited a greater number of U-turns, 7 weeks post injury. Tucker and coworkers exposed male mice to a single $900 \mathrm{mV}, 10 \mathrm{~ms}$ wave generated from a high intensity focused ultrasound device (95). Ultrasound exposed mice exhibited reduced time in the open regions of the zero maze 4 days post injury, compared to shamtreated animals. Overall, it seems that TBI has an anxiolytic-like effect on rodent behavior in the zero maze test, but further study is needed.

\section{Open field test}

The open field test, originally developed by Hall (132), has become one of the most frequently employed tests for measuring spontaneous activity (72). Investigators have traditionally employed this test as a measure of "emotionality" (132-134). In the open field procedure, the animal is initially placed in the center of the apparatus (usually $40 \mathrm{~cm} \times 40 \mathrm{~cm} \times 30 \mathrm{~cm} ; \mathrm{W} \times \mathrm{L} \times \mathrm{H}$ box) and the following behaviors are recorded for 2-20 min: horizontal locomotion, frequency of rearing, grooming, freezing, number of fecal boli deposited, and the proportion of time spent in the center of the arena (72).

In addition to being the most widely used assessment of general activity, the open field test was one of the earliest tools that was applied to evaluate the incidence of freezing and defecation as measures of anxiety-like behaviors $(135,136)$. The relative amount of time that a mouse or rat spends in the center of the open field area versus the peripheral region is likewise considered a measure of anxiety; rodents are exploratory but will generally stay near the walls of the open field [for review, see Ref. $(72,137)$ ]. There are two naturalistic factors that trigger anxiety-like behaviors in the open field: agoraphobia (the arena is very large relative to the animal's natural environment) and individual testing (the animal is separated from its social group). These two factors trigger anxiety-like behavior in rodents that live in social groups and in small tunnels (138). Pharmaceutical agents such as benzodiazepines, serotoninergic ligands, opiates, and dopaminergic agents all decrease anxiety-like behaviors of rodents in the open field, suggesting that this test is appropriate for studying anxiety in mice and rats (139-142).

Many studies have explored the effects of TBI on motor activity and anxiety-like behaviors of rodents in the open field. Rats with a TBI in the right parietal cortex induced by CCI $(6 \mathrm{~mm}$ impact tip diameter; velocity $4 \mathrm{~m} / \mathrm{s}$ ) were no different than sham controls 13 days after injury on measures of activity and exploratory behavior in the open field (98). Another study (79) employed the FPI model and also found no significant differences between injured rats (FPI $-4 \mathrm{~mm}$ lateral and $4 \mathrm{~mm}$ posterior to bregma; 3.2-3.5 atmospheres of pressure pulse over $21-23 \mathrm{~ms}$ ) and their controls. These animals were evaluated for the total distance traveled in the apparatus, 1, 3, and 6 months after injury. However, injured rats spent less time exploring the center of the open field compared to sham controls, suggesting some difference in level of anxiety as a function of FPI. Fromm and colleagues (97) showed that TBI rats, induced by a 450-g weight dropped from a 2-m height on a $10-\mathrm{mm}$ diameter disk (placed on the exposed skull, between the lambda and bregma sutures), exhibited significantly less spontaneous activity in the open field 7 days post injury, compared to 
pre-injury results. Using the same injury method and parameters, measures found injured rats performed significantly poorer in activity measurements as well as anxiety-like behavior measurements. TBI animals were more stationary; traveled less distance in the arena; less explorative; explored only the corners of the apparatus. Another study, using similar weight-drop parameters, found persistent decreased open field activity for up to 4 weeks after injury (96). As opposed to the studies mentioned above, Pandey and colleagues (92) found that injured rats exhibited increases in several activity parameters in the open field model, 14 days after injury induction, compared to their sham controlled rats.

Activity level changes in mice follow a more consistent pattern. Wakade and colleagues (99) found that CD-1 mice, 7 days following a moderate TBI induced by CCI $(3.5 \mathrm{~mm}$ craniotomy midway between the bregma and lambda), exhibited hyperactivity in the open field test, compared to their sham controls. Kimbler and colleagues observed that CCI-injured mice exhibited an increase in distance traveled compared to sham-operated animals 3 days after injury (88). Yu and colleagues examined the effects of brain injury 10 days after post-CCI $(3 \mathrm{~mm}$ tip, $2 \mathrm{~mm}$ depth, $5 \mathrm{~m} / \mathrm{s}$ ); the injury resulted in mice that were hyperactive in terms of distance traveled, but the animals spent less time in the center (100). Budinich and colleagues reported that CCI ( $3 \mathrm{~mm}$ impactor, $1.0 \mathrm{~mm}$ depth of impact, $5 \mathrm{~m} / \mathrm{s}$, dwell time of $0.1 \mathrm{~s}$ ) caused mice to exhibit increased mobility on 1, 7, and 14 days after injury, but that they spent less time in the center of the open field (101). Similar instances of "hyperactivity" have been observed in our laboratory for several weeks post-TBI: Tucker and colleagues (102) studied mice that sustained either mild (impact depth $1.0 \mathrm{~mm}$ ) or severe (depth $2.0 \mathrm{~mm}$ ) CCI ( $3 \mathrm{~mm}$ impactor tip, velocity $5 \mathrm{~m} / \mathrm{s}$ ). Schwarzbold and colleagues found similar results: 10 days after TBI induction, injured mice (of the 15 -g weight group) exhibited higher locomotor activity compared to mice from other control groups (84). Animals that sustained severe CCI were hyperactive with less time spent in the center. Following mechanical stimulation by HIFU, however, animals were hypoactive in the open field (95) for at least 1 week post-TBI. Likewise, Tweedie and colleagues found no differences between sham-treated and injured mice in the percentage changes in distance traveled by mice 3 days after TBI (83).

The results from rat studies, regarding activity measurements in the open field test after TBI induction, are inconclusive. It is important to note that different laboratories do not only use different models of TBI, but also use different strains of rats (e.g., CD-1, Wistar, Sprague-Dawley, etc.). Therefore, additional research of the effect of TBI on activity, as well as on anxiety-like behavior in the open field test is essential. For studies with TBI in mice, there is greater consistency in findings where the general finding is an increase in activity.

\section{Light/dark test}

Analogous to the elevated-plus maze, the light/dark test is based on the conflict between the tendency of mice to explore a novel environment versus the aversive properties of a brightly lit open field (143). The typical dimensions of the light/dark test apparatus for mouse use are $46 \mathrm{~cm} \times 27 \mathrm{~cm} \times 30 \mathrm{~cm}(\mathrm{~L} \times \mathrm{W} \times \mathrm{H})$ and it is divided into two parts: an opaque, covered chamber, considered by a rodent to be the "safe" compartment (approximately one-third of the apparatus), and a larger, illuminated "aversive" compartment, which is a transparent, uncovered arena that is illuminated by an overhead lamp. Rodents that exhibit anxiety-like behavior will spend significantly more time in the dark, "safe" compartment compared to their controls. Crawley and Goodwin (143) showed that anxiolytic drugs (benzodiazepines) facilitated exploratory behavior; mice spent more time in the illuminated open area as a result of the treatment. Indeed, multiple subsequent studies have shown that anxiolytic drugs increase locomotion and time spent in the light "aversive" compartment, while anxiogenic compounds decrease locomotion and time spent in this compartment [for review, see Ref. (144)]. Few studies appear to have investigated the effects of TBI on the behavior of rodents in the light/dark test. Cope and colleagues report that TBI rats (induced by CCI to the medial frontal cortex) spent less time in the lighted arena and made fewer crossings between the different zones 8 days after injury (80), exhibiting anxiety-like behavior.

\section{IRRITABILITY}

"Irritability" has been recognized as a state that can be evaluated in rodents. It has been described as a condition where the animal exhibits "wild" and/or restlessness in response to a perceptible stimulus (145), and as an extreme reaction to relatively mild stimuli (146). However, as opposed to aggression and impulsivity, irritability - in humans - is not just behaviorally defined, but involves subjective state changes (147); therefore, the modeling of irritability in rodents is conceptually complicated. A variety of drugs such as parachlorophenylalanine (148) and trimethyltin (149), and imidazole (150) can provoke this state. Likewise, psychoactive drug withdrawal, especially for opiate drugs, reportedly most robustly elicits this state $(151,152)$.

The two most commonly used tests for evaluation are resistance to capture or attempts to struggle while being restrained (153), and responsiveness to uncomfortable stimuli. Tests also include assessing rodent struggling behavior in response to human handling. As a response to moderate restraint applied by the handler, a mouse will either exhibit a passive or irritated response. The extent and duration of struggling behavior are used as metrics (153). Tests of responsiveness to a uniformly uncomfortable situation have also been employed. An uncomfortable stimulus is given (e.g., a white bottle brush moving against the animal or a puff of air blown sharply through a straw onto the back of the animal's neck) and the animal's response is quantified. Animals that exhibit enhanced reactivity to the stimuli are considered to display irritable behavior (146). Irritability as a post-TBI symptom is undoubtedly important clinically and testing in animal models may shed light on this complex symptom. However, a review of the literature found no studies that have examined this post-TBI.

\section{AGGRESSION}

Beginning in the juvenile phase of development, rodents establish dominance hierarchies, and engage in fighting behavior (154). Indeed, rodent aggression behavior has been described in detail in many laboratories (155). Experts suggest laboratory studies 
with rodents mirror at least some aspects of aggression in humans (156). Several behavioral tests assess aggression in rodents, including the tube test (157) and the standard opponent method (158). However, the most widely employed assessment is the resident-intruder test (159).

\section{Resident-intruder test}

In the resident-intruder test, an "intruder," usually a naïve, weightand age-matched mouse (weight and age are crucial components affecting aggression behavior in rodents), is placed into "the home cage," that the experimental mouse has been housed in for an extended period of time: the intruder elicits territorial attacks from the male resident in the home cage (72). Usually, a 5-min residentintruder session is conducted [although test sessions vary from 2 to $30 \mathrm{~min}$ (160)] and videotaped recordings are used for subsequent scoring by the investigator. The investigator scores the frequency and the length of the following behaviors: attack bites - biting of the intruder mice; tail rattling - rapid lateral quivering of the tail, just before or after attacking; wrestling - vigorous shoving and sparring when both animals take on an upright posture, usually performed by both animals simultaneously; chasing behavior rapid pursuit of the intruder by the test male, with or without physical contact; and attack latency-latency time to the first attack (in seconds) from the introduction of the intruder mouse.

Numerous studies have found that acute (but not chronic) treatment with antidepressants has been able to reduce aggressive behavior in the resident-intruder test in rats, including: SSRIs, serotonin-norepinephrine reuptake inhibitors, monoamine oxidase inhibitors (MAOIs), tricyclic antidepressants (TCAs) and atypical antidepressants such as mainserin and iprindole (161). Mouse aggressive behavior, on the other hand, has been found to be sensitive to anxiolytic drugs rather than antidepressants in the resident-intruder test (162). Lumley et al. (162) proposed that this difference in response between mice and rats is due to the functional differences in aggressive behavior between these species: while mice violently defend their territory, rats live in social colonies where excessive agonistic behavior is harmful to the social group.

Semple and colleagues (103) evaluated social behavior, including aggressive behavior, in mice subjected to TBI at post-natal day (pd) 21. The resident-intruder test was conducted twice - once in the adolescence phase ( $\mathrm{pd}$ 35-42) and during early adulthood ( $\mathrm{pd}$ 60-70). The researchers found that despite normal olfactory function and normal social behavior during adolescence, injured mice exhibited impaired social investigation in the resident-intruder test by adulthood; injured mice displayed reduced anogenital sniffing and following compared to their controls. In addition, by adulthood, injured mice showed more frequent dominance in the tube task compared to their sham controls, suggesting aggressive tendencies in the TBI mice. No studies have been conducted on the effect of TBI on aggression behavior in rats. However, lesion studies have been a classic approach for delineating systems related to aggression and integration with this field is warranted $(163,164)$.

\section{SUICIDE}

Suicide is a complex human behavior and is an aftereffect in many cases of TBI. Unfortunately, there are no existing animal models for suicide per se. Studies have tried to identify personality traits that are risk factors for suicidal behavior $(165,166)$, and the four major risk factors that have been found to be common for most of the studies were aggression, impulsivity, irritability, and hopelessness/helplessness [for a thorough review of these risk factors and their animal models, see Ref. (161)]. As reviewed earlier, all of these behaviors are amenable to modeling in rodents, providing an opportunity to determine neurobiological mechanisms relating brain injury and suicidality.

\section{SUMMARY}

The simulation of TBI-relevant neuropsychiatric symptoms in pre-clinical rodent models is a critical step for further understanding basic molecular and structural relationships and for the development of therapeutic approaches. As noted earlier, some symptom profiles in the realm of motor and cognitive function have received wide employment in pre-clinical TBI research. For example, this literature review found popular and suitable motor tests include the beam walk test, rotarod, and neurological assessment scales. Likewise, the Morris water swim test and open field test are conventionally employed for cognitive assessment. Neuropsychiatric impairments have received less attention in animal models of TBI and are recognized as a challenge. Table 2 summarizes the status of emotional systems testing in rats and mice after TBI. The literature suggests "hyperactivity" is seen in the open field test in mice after TBI, and one study found anxiety responses in the Light/Dark Test. One study has employed the Resident-Intruder Test as a measure of aggression and social behavior. However, few tests were found that employed other tests of emotional systems that have received quite wide use in the psychopharmacology field.

Rodent models cannot replicate "higher" cognitive-emotional reactions and expectations of individuals and their social milieu, and how the patient must learn to cope with the knowledge of personal mental and/or physical impairment(s) and potential limitations in adjusting to life's many challenges. Animal models, then, have limitations in ability to fully mimic the human condition. Likewise, "There is no way for a human investigator to know whether a mouse is feeling afraid, anxious, or depressed.... What we can do is observe the behavioral and physiological responses that a mouse makes to stimuli and events" (72). In spite of limitations, neuropsychiatric symptomatology from TBI related to depression, anxiety, irritability, and aggression are major aspects of human suffering, and require continued and concerted efforts related to etiology and therapeutics.

\section{ACKNOWLEDGMENTS}

The opinions, interpretations, conclusions, and recommendations are those of the authors and are not necessarily endorsed by the US Army, Department of Defense, the US government, or the Uniformed Services University of the Health Sciences. The use of trade names does not constitute an official endorsement or approval of the use of such reagents or commercial hardware or software. This document may not be cited for purposes of advertisement. Supported by the Center for Neuroscience and Regenerative Medicine, USUHS. 


\section{REFERENCES}

1. Beauchamp K, Mutlak H, Smith WR, Shohami E, Stahel PF. Pharmacology of traumatic brain injury - where is the "golden bullet"? Mol Med (2008) 14:731-40. doi:10.2119/200800050.Beauchamp

2. Loane DJ, Faden AI. Neuroprotection for traumatic brain injury: translational challenges and emerging therapeutic strategies. Trends Pharmacol Sci (2010) 31:596-604. doi:10.1016/j.tips.2010.09.005

3. Maas AI, Roozenbeek B, Manley GT. Clinical trials in traumatic brain injury: past experience and current developments. Neurotherapeutics (2010) 7:115-26. doi:10. 1016/j.nurt.2009.10.022

4. Wheaton P, Mathias JL, Vink R. Impact of pharmacological treatments on outcome in adult rodents after traumatic brain injury: a meta-analysis. J Psychopharmacol (2011) 25:1581-99. doi:10.1177/ 0269881110388331

5. Statler KD, Jenkins LW, Dixon CE, Clark RS, Marion DW, Kochanek PM. The simple model versus the super model: translating experimental traumatic brain injury research to the bedside. J Neurotrauma (2001) 18:1195-206. doi: 10.1089/089771501317095232

6. Cernak I. Animal models of head trauma. NeuroRx (2005) 2:410-22. doi:10.1602/neurorx.2.3.410

7. Kazanis I. CNS injury research; reviewing the last decade: methodological errors and a proposal for a new strategy. Brain Res Brain Res Rev (2005) 50:377-86. doi:10. 1016/j.brainresrev.2005.09.003

8. Morales DM, Marklund N, Lebold D, Thompson HJ, Pitkanen A, Maxwell WL, et al. Experimental models of traumatic brain injury: do we really need to build a better mousetrap? Neuroscience (2005) 136:971-89. doi:10.1016/j. neuroscience.2005.08.030

9. Marklund N, Hillered L. Animal modeling of traumatic brain injury in pre-clinical drug development - where do we go from here? Br J Pharmacol (2011) 164:1207-29. doi:10.1111/j.14765381.2010.01163.x

10. Hamm RJ. Neurobehavioral assessment of outcome following traumatic brain injury in rats: an evaluation of selected measures. $J$ Neurotrauma (2001) 18:1207-16. doi:10.1089/089771501317095241

11. Fujimoto ST, Longhi L, Saatman KE, Conte V, Stocchetti N,
McIntosh TK. Motor and cognitive function evaluation following experimental traumatic brain injury. Neurosci Biobehav Rev (2004) 28:365-78. doi:10.1016/j. neubiorev.2004.06.002

12. Shelton SB, Pettigrew DB, Hermann AD, Zhou W, Sullivan $\mathrm{PM}$, Crutcher KA, et al. A simple, efficient tool for assessment of mice after unilateral cortex injury. J Neurosci Methods (2008) 168:431-42. doi:10.1016/j. jneumeth.2007.11.003

13. Bales JW, Wagner AK, Kline AE, Dixon CE. Persistent cognitive dysfunction after traumatic brain injury: a dopamine hypothesis. Neurosci Biobehav Rev (2009) 33:981-1003. doi:10.1016/ j.neubiorev.2009.03.011

14. National Center for Injury Prevention and Control. Traumatic Brain Injury in the United States: A Report to Congress. Atlanta, GA: Centers for Disease Control and Prevention (1999).

15. National Center for Injury Prevention and Control. Report to Congress on Mild Traumatic Brain Injury in the United States: Steps to Prevent a Serious Public Health Problem. Atlanta, GA: Centers for Disease Control and Prevention (2003).

16. Cassidy JD, Carroll LJ, Peloso PM, Borg J, von Holst H, Holm L, et al. Incidence, risk factors and prevention of mild traumatic brain injury: results of the WHO Collaborating Centre Task Force on Mild Traumatic Brain Injury. J Rehabil Med (2004) (Suppl 43):28-60. doi:10.1080/16501960410023732

17. Pellman EJ, Viano DC. Concussion in professional football: summary of the research conducted by the National Football League's Committee on Mild Traumatic Brain Injury. Neurosurg Focus (2006) 21:E12. doi:10.3171/foc.2006.21.4. 13

18. McCrea MA. Mild Traumatic Brain Injury and Postconcussion Syndrome: The New Evidence Base for Diagnosis and Treatment. Oxford: Oxford University Press (2008).

19. Silver JM, McAllister TW, Arciniegas DB. Depression and cognitive complaints following mild traumatic brain injury. Am J Psychiatry (2009) 166:653-61. doi:10. 1176/appi.ajp.2009.08111676

20. French LM. Military traumatic brain injury: an examination of important differences. Ann N $Y$ Acad Sci (2010) 1208:38-45. doi:10.1111/j.1749-6632.2010. 05696.x

21. Bruns JJ Jr, Jagoda AS. Mild traumatic brain injury. Mt Sinai J Med (2009) 76:129-37. doi:10. 1002/msj.20101

22. Bazarian JJ, Atabaki S. Predicting postconcussion syndrome after minor traumatic brain injury. Acad Emerg Med (2001) 8:788-95. doi:10.1111/j.1553-2712.2001. tb00208.x

23. Rutherford WH, Merrett JD, McDonald JR. Symptoms at one year following concussion from minor head injuries. Injury (1979) 10:225-30. doi:10.1016/00201383(79)90015-9

24. Wolf SJ, Bebarta VS, Bonnett CJ, Pons PT, Cantrill SV. Blast injuries. Lancet (2009) 374:405-15. doi:10. 1016/S0140-6736(09)60257-9

25. Bazarian JJ, Cernak I, NobleHaeusslein L, Potolicchio S, Temkin N. Long-term neurologic outcomes after traumatic brain injury. J Head Trauma Rehabil (2009) 24:439-51. doi:10.1097/ HTR.0b013e3181c15600

26. Dikmen SS, Corrigan JD, Levin HS, Machamer J, Stiers W, Weisskopf MG. Cognitive outcome following traumatic brain injury. J Head Trauma Rehabil (2009) 24:430-8. doi:10.1097/HTR. 0b013e3181c133e9

27. Dashnaw ML, Petraglia AL, Bailes JE. An overview of the basic science of concussion and subconcussion: where we are and where we are going. Neurosurg Focus (2012) 33:E5: 1-9. doi:10. 3171/2012.10.FOCUS12284

28. Shively S, Scher AI, Perl DP, Diaz-Arrastia R. Dementia resulting from traumatic brain injury: what is the pathology? Arch Neurol (2012) 69:1245-51. doi:10.1001/ archneurol.2011.3747

29. Silver JM, Kramer R, Greenwald $\mathrm{S}$, Weissman M. The association between head injuries and psychiatric disorders: findings from the New Haven NIMH Epidemiologic Catchment Area Study. Brain Inj (2001) 15:935-45. doi:10.1080/ 02699050110065295

30. Ashman TA, Gordon WA, Cantor JB, Hibbard MR. Neurobehavioral consequences of traumatic brain injury. Mt Sinai J Med (2006) 73:999-1005.

31. Riggio S, Wong M. Neurobehavioral sequelae of traumatic brain injury. Mt Sinai J Med (2009) 76:163-72. doi:10.1002/msj.20097

32. van Reekum R, Cohen T, Wong J. Can traumatic brain injury cause psychiatric disorders? J Neuropsychiatry Clin Neurosci (2000) 12:316-27. doi:10.1176/ appi.neuropsych.12.3.316

33. Alderfer BS, Arciniegas DB, Silver JM. Treatment of depression following traumatic brain injury. J Head Trauma Rehabil (2005) 20:544-62. doi:10.1097/ 00001199-200511000-00006

34. Rogers JM, Read CA. Psychiatric comorbidity following traumatic brain injury. Brain Inj (2007) 21:1321-33. doi:10.1080/ 02699050701765700

35. Jorge RE, Robinson RG, Starkstein SE, Arndt SV. Depression and anxiety following traumatic brain injury. J Neuropsychiatry Clin Neurosci (1993) 5:369-74.

36. Holsinger T, Steffens DC, Phillips C, Helms MJ, Havlik RJ, Breitner JC, et al. Head injury in early adulthood and the lifetime risk of depression. Arch Gen Psychiatry (2002) 59:17-22. doi:10.1001/ archpsyc.59.1.17

37. Vaishnavi S, Rao V, Fann JR. Neuropsychiatric problems after traumatic brain injury: unraveling the silent epidemic. Psychosomatics (2009) 50:198-205. doi:10. 1176/appi.psy.50.3.198

38. Hibbard MR, Ashman TA, Spielman LA, Chun D, Charatz HJ, Melvin S. Relationship between depression and psychosocial functioning after traumatic brain injury. Arch Phys Med Rehabil (2004) 85:S43-53. doi:10.1016/j. apmr.2003.08.116

39. Fann JR, Katon WJ, Uomoto JM, Esselman PC. Psychiatric disorders and functional disability in outpatients with traumatic brain injuries. Am J Psychiatry (1995) 152:1493-9.

40. Hibbard MR, Uysal S, Kepler K, Bogdany J, Silver J. Axis I psychopathology in individuals with traumatic brain injury. J Head Trauma Rehabil (1998) 13:24-39. doi:10.1097/00001199. 199808000-00005

41. Mooney G, Speed J. The association between mild traumatic brain injury and psychiatric conditions. Brain Inj (2001) 15:865-77. doi:10. 1080/02699050110065286

42. Deb S, Burns J. Neuropsychiatric consequences of traumatic brain injury: a comparison between two age groups. Brain Inj (2007) 21:301-7. doi:10.1080/02699050701253137

43. Terrio H, Brenner LA, Ivins BJ, Cho JM, Helmick K, Schwab 
$\mathrm{K}$, et al. Traumatic brain injury screening: preliminary findings in a US Army Brigade Combat Team. J Head Trauma Rehabil (2009) 24:14-23. doi:10.1097/ HTR.0b013e31819581d8

44. Yang CC, Hua MS, Lin WC, Tsai YH, Huang SJ. Irritability following traumatic brain injury: divergent manifestations of annoyance and verbal aggression. Brain Inj (2012) 26:1185-91. doi:10.3109/ 02699052.2012 .666374

45. Snaith RP, Taylor CM. Irritability: definition, assessment and associated factors. Br J Psychiatry (1985) 147:127-36. doi:10.1192/bjp.147. 2.127

46. O'Connor C, Colantonio A, Polatajko H. Long term symptoms and limitations of activity of people with traumatic brain injury: a ten-year follow-up. Psychol Rep (2005) 97:169-79. doi:10.2466/pr0.97.1.169-179

47. Brezo J, Paris J, Turecki G. Personality traits as correlates of suicidal ideation, suicide attempts, and suicide completions: a systematic review. Acta Psychiatr Scand (2006) 113:180-206. doi:10.1111/ j.1600-0447.2005.00702.x

48. Conner KR, Meldrum S, Wieczorek WF, Duberstein PR, Welte JW. The association of irritability and impulsivity with suicidal ideation among 15 - to 20year-old males. Suicide Life Threat Behav (2004) 34:363-73. doi:10. 1521/suli.34.4.363.53745

49. Omalu B, Hammers JL, Bailes J, Hamilton RL, Kamboh MI, Webster G, et al. Chronic traumatic encephalopathy in an Iraqi war veteran with posttraumatic stress disorder who committed suicide. Neurosurg Focus (2011) 31:E3. doi: 10.3171/2011.9.FOCUS11178

50. Hammond FM, Davis CS, Cook JR, Philbrick P, Hirsch MA. Relational dimension of irritability following traumatic brain injury: a qualitative analysis. Brain Inj (2012) 26:1287-96. doi:10.3109/ 02699052.2012.706352

51. Buss AH, Durkee A. An inventory for assessing different kinds of hostility. J Consult Psychol (1957) 21:343-9. doi:10.1037/ h0046900

52. Greve KW, Sherwin E, Stanford MS, Mathias C, Love J, Ramzinski P. Personality and neurocognitive correlates of impulsive aggression in long-term survivors of severe traumatic brain injury. Brain Inj (2001) 15:255-62. doi:10.1080/ 026990501300005695
53. Wood RL. Conditioning procedures in brain injury rehabilitation. In: Wood RL, editor. Neurobehavioral Sequelae of Traumatic Brain Injury. New York: Taylor Francis (1990). p. 153-74.

54. Kerr K, Oram J, Tinson H, Shum D. The correlates of aggression in people with acquired brain injury: a preliminary retrospective study. Brain Inj (2011) 25:729-41. doi:10. 3109/02699052.2011.580315

55. Kim E, Lauterbach EC, Reeve A, Arciniegas DB, Coburn KL, Mendez MF, et al. Neuropsychiatric complications of traumatic brain injury: a critical review of the literature (a report by the ANPA Committee on Research). J Neuropsychiatry Clin Neurosci (2007) 19:106-27. doi:10.1176/ appi.neuropsych.19.2.106

56. Dyer KF, Bell R, McCann J, Rauch R. Aggression after traumatic brain injury: analysing socially desirable responses and the nature of aggressive traits. Brain Inj (2006) 20:1163-73. doi:10.1080/ 02699050601049312

57. Tateno A, Jorge RE, Robinson RG. Clinical correlates of aggressive behavior after traumatic brain injury. J Neuropsychiatry Clin Neurosci (2003) 15:155-60. doi:10. 1176/appi.neuropsych.15.2.155

58. Rao V, Rosenberg P, Bertrand M, Salehinia S, Spiro J, Vaishnavi $\mathrm{S}$, et al. Aggression after traumatic brain injury: prevalence and correlates. J Neuropsychiatry Clin Neurosci (2009) 21:420-9. doi:10. 1176/appi.neuropsych.21.4.420

59. Dumais A, Lesage AD, Alda M, Rouleau G, Dumont M, Chawky N, et al. Risk factors for suicide completion in major depression: a casecontrol study of impulsive and aggressive behaviors in men. Am J Psychiatry (2005) 162:2116-24. doi:10.1176/appi.ajp.162.11.2116

60. Burns S, Kappenberg R, McKenna A, Wood C. Brain injury: personality, psychopathology and neuropsychology. Brain Inj (1994) 8:413-27. doi:10.3109/02699059409150993

61. Persinger MA. Sense of a presence and suicidal ideation following traumatic brain injury: indications of right-hemispheric intrusions from neuropsychological profiles. Psychol Rep (1994) 75:1059-70. doi:10.2466/pr0.1994.75.3.1059

62. Mann JJ, Waternaux C, Haas GL, Malone KM. Toward a clinical model of suicidal behavior in psychiatric patients. Am J Psychiatry (1999) 156:181-9.
63. Simpson G, Tate R. Suicidality after traumatic brain injury: demographic, injury and clinical correlates. Psychol Med (2002) 32:687-97. doi:10.1017/S0033291702005561

64. Teasdale TW, Engberg AW. Suicide after traumatic brain injury: a population study. $J$ Neurol Neurosurg Psychiatry (2001) 71:436-40. doi:10.1136/jnnp.71.4. 436

65. Skopp NA, Trofimovich L, Grimes J, Oetjen-Gerdes L, Gahm GA. Relations between suicide and traumatic brain injury, psychiatric diagnoses, and relationship problems, active component, U.S. Armed Forces, 2001-2009. MSMR (2012) 19:7-11.

66. Achté KA, Lönnqvist J, Hillbom E. Suicides following war braininjuries. Acta Psychiatr Scand Suppl (1971) 225:1-94.

67. Klonoff PS, Lage GA. Suicide in patients with traumatic brain injury: risk and prevention. J Head Trauma Rehabil (1995) 10:16-24. doi:10.1097/00001199199512000-00005

68. Tate R, Simpson G, Flanagan S, Coffey M. Completed suicide after traumatic brain injury. J Head Trauma Rehabil (1997) 12:16-28. doi:10.1097/00001199199712000-00003

69. Lewin W, Marshall TF, Roberts AH. Long-term outcome after severe head injury. $\mathrm{Br}$ Med $J$ (1979) 2:1533-8. doi:10.1136/bmj.2.6204. 1533

70. Shavelle RM, Strauss D, Whyte J, Day SM, Yu YL. Long-term causes of death after traumatic brain injury. Am J Phys Med Rehabil (2001) 80:510-6; quiz 517-519. doi:10.1097/00002060200107000-00009

71. American Psychiatric Association. Diagnostic and Statistical Manual of Mental Disorders - (DSM IV). 4th ed. Washington, DC: American Psychiatric Association (2000).

72. Crawley JC. What's Wrong with My Mouse? 2nd ed. Hoboken, NJ: John Wiley \& Sons, Inc (2007).

73. Sclafani A. Sucrose motivation in sweet "sensitive" (C57BL/6J) and "subsensitive" (129P3/J) mice measured by progressive ratio licking. Physiol Behav (2006) 87:734-44. doi:10.1016/j.physbeh. 2006.01.017

74. Willner P, Towell A, Sampson D, Sophokleous S, Muscat R. Reduction of sucrose preference by chronic unpredictable mild stress, and its restoration by a tricyclic antidepressant. Psychopharmacology (Berl) (1987) 93:358-64. doi: 10.1007/BF00187257

75. Pucilowski O, Overstreet DH, Rezvani AH, Janowsky DS. Chronic mild stress-induced anhedonia: greater effect in a genetic rat model of depression. Physiol Behav (1993) 54:1215-20. doi:10.1016/ 0031-9384(93)90351-F

76. Harris RB, Zhou J, Youngblood BD, Rybkin II, Smagin GN, Ryan DH. Effect of repeated stress on body weight and body composition of rats fed low- and highfat diets. Am J Physiol (1998) 275:R1928-38.

77. Pijlman FT, Wolterink G, Van Ree JM. Physical and emotional stress have differential effects on preference for saccharine and open field behaviour in rats. Behav Brain Res (2003) 139:131-8. doi: 10.1016/S0166-4328(02)00124-9

78. Forbes NF, Stewart CA, Matthews K, Reid IC. Chronic mild stress and sucrose consumption: validity as a model of depression. Physiol Behav (1996) 60:1481-4. doi:10.1016/S0031-9384(96) 00305-8

79. Jones NC, Cardamone L, Williams JP, Salzberg MR, Myers D, O’Brien TJ. Experimental traumatic brain injury induces a pervasive hyperanxious phenotype in rats. $\mathrm{J} \mathrm{Neu}$ rotrauma (2008) 25:1367-74. doi: 10.1089/neu.2008.0641

80. Cope EC, Morris DR, Scrimgeour AG, Levenson CW. Use of zinc as a treatment for traumatic brain injury in the rat: effects on cognitive and behavioral outcomes. Neurorehabil Neural Repair (2012) 26:907-13. doi:10.1177/ 1545968311435337

81. Milman A, Rosenberg A, Weizman R, Pick CG. Mild traumatic brain injury induces persistent cognitive deficits and behavioral disturbances in mice. J Neurotrauma (2005) 22:1003-10. doi:10.1089/ neu.2005.22.1003

82. Taylor AN, Rahman SU, Tio DL, Sanders MJ, Bando JK, Truong $\mathrm{AH}$, et al. Lasting neuroendocrineimmune effects of traumatic brain injury in rats. J Neurotrauma (2006) 23:1802-13. doi:10.1089/ neu.2006.23.1802

83. Tweedie D, Milman A, Holloway HW, Li Y, Harvey BK, Shen H, et al. Apoptotic and behavioral sequelae of mild brain trauma in mice. J Neurosci Res (2007) 85:805-15. doi:10.1002/jnr.21160

84. Schwarzbold ML, Rial D, De Bem T, Machado DG, Cunha MP, Dos 
Santos AA, et al. Effects of traumatic brain injury of different severities on emotional, cognitive, and oxidative stress-related parameters in mice. I Neurotrauma (2010) 27:1883-93. doi:10.1089/ neu.2010.1318

85. Wang Y, Neumann M, Hansen K, Hong SM, Kim S, NobleHaeusslein LJ, et al. Fluoxetine increases hippocampal neurogenesis and induces epigenetic factors but does not improve functional recovery after traumatic brain injury. J Neurotrauma (2011) 28:259-68. doi:10.1089/neu.2010. 1648

86. Washington PM, Forcelli PA, Wilkins T, Zapple DN, Parsadanian M, Burns MP. The effect of injury severity on behavior: a phenotypic study of cognitive and emotional deficits after mild, moderate, and severe controlled cortical impact injury in mice. J Neurotrauma (2012) 29:2283-96. doi:10.1089/neu. 2012.2456

87. Shultz SR, Bao F, Omana V, Chiu C, Brown A, Cain DP. Repeated mild lateral fluid percussion brain injury in the rat causes cumulative long-term behavioral impairments, neuroinflammation, and cortical loss in an animal model of repeated concussion. J Neurotrauma (2012) 29:281-94. doi:10. 1089/neu.2011.2123

88. Kimbler DE, Shields J, Yanasak N, Vender JR, Dhandapani KM. Activation of $\mathrm{P} 2 \mathrm{X} 7$ promotes cerebral edema and neurological injury after traumatic brain injury in mice. PLoS One (2012) 7(7):e41229. doi:10.1371/journal. pone.0041229

89. Ando T, Xuan W, Xu T, Dai T, Sharma SK, Kharkwal GB, et al. Comparison of therapeutic effects between pulsed and continuous wave $810-\mathrm{nm}$ wavelength laser irradiation for traumatic brain injury in mice. PLoS One (2011) 6:e26212. doi:10.1371/ journal.pone.0026212

90. Vuckovic MG, Wood RI, Holschneider DP, Abernathy A, Togasaki DM, Smith A, et al. Memory, mood, dopamine, and serotonin in the 1-methyl-4-phenyl1,2,3,6-tetrahydropyridinelesioned mouse model of basal ganglia injury. Neurobiol Dis (2008) 32:319-27. doi:10.1016/j.nbd.2008.07.015

91. Cutler SM, Vanlandingham JW, Murphy AZ, Stein DG. Slowrelease and injected progesterone treatments enhance acute recovery after traumatic brain injury. Pharmacol Biochem Behav (2006) 84:420-8. doi:10.1016/j.pbb.2006. 05.029

92. Pandey DK, Yadav SK, Mahesh R, Rajkumar R. Depression-like and anxiety-like behavioural aftermaths of impact accelerated traumatic brain injury in rats: a model of comorbid depression and anxiety? Behav Brain Res (2009) 205:436-42. doi:10.1016/j. bbr.2009.07.027

93. Ajao DO, Pop V, Kamper JE, Adami A, Rudobeck E, Huang L, et al. Traumatic brain injury in young rats leads to progressive behavioral deficits coincident with altered tissue properties in adulthood. $\mathrm{JNeu}$ rotrauma (2012) 29:2060-74. doi: $10.1089 /$ neu.2011.1883

94. Siopi E, Llufriu-Daben G, Fanucchi F, Plotkine M, MarchandLeroux C, Jafarian-Tehrani M. Evaluation of late cognitive impairment and anxiety states following traumatic brain injury in mice: the effect of minocycline. Neurosci Lett (2012) 511:110-5. doi:10.1016/j.neulet.2012.01.051

95. Tucker LB, Fu A, Fortin LA, Malkesman O, McCabe JT. Behavioral changes after traumatic brain injury induced by highintensity focused ultrasound in the laboratory mouse. Society for Neuroscience Abstracts, Program No. 553.506. New Orleans, LA: Society for Neuroscience (2012).

96. O'Connor C, Heath DL, Cernak I, Nimmo AJ, Vink R. Effects of daily versus weekly testing and pretraining on the assessment of neurologic impairment following diffuse traumatic brain injury in rats. J Neurotrauma (2003) 20:985-93. doi:10.1089/089771503770195830

97. Fromm L, Heath DL, Vink R, Nimmo AJ. Magnesium attenuates post-traumatic depression/anxiety following diffuse traumatic brain injury in rats. J Am Coll Nutr (2004) 23:529S-33. doi:10.1080/ 07315724.2004.10719396

98. Wagner AK, Kline AE, Ren D, Willard LA, Wenger MK, Zafonte $\mathrm{RD}$, et al. Gender associations with chronic methylphenidate treatment and behavioral performance following experimental traumatic brain injury. Behav Brain Res (2007) 181:200-9. doi:10.1016/j. bbr.2007.04.006

99. Wakade C, Sukumari-Ramesh S, Laird MD, Dhandapani KM, Vender JR. Delayed reduction in hippocampal postsynaptic density protein-95 expression temporally correlates with cognitive dysfunction following controlled cortical impact in mice. J Neurosurg (2010) 113:1195-201. doi:10.3171/2010.3.JNS091212

100. Yu F, Wang Z, Tchantchou F, Chiu CT, Zhang Y, Chuang DM. Lithium ameliorates neurodegeneration, suppresses neuroinflammation, and improves behavioral performance in a mouse model of traumatic brain injury. $J$ Neurotrauma (2012) 29:362-74. doi:10. 1089/neu.2011.1942

101. Budinich CS, Tucker LB, Lowe D, Rosenberger JG, McCabe JT. Short and long-term motor and behavioral effects of diazoxide and dimethyl sulfoxide administration in the mouse after traumatic brain injury. Pharmacol Biochem Behav (2013) 108:66-73. doi:10.1016/j. pbb.2013.04.001

102. Tucker L, Fu A, Ozl J, Duncklee G, Malkesman O, McCabe J. Microanalysis of open field behavior following controlled cortical impact in mice. J Neurotrauma (2013) 30:A1-32.

103. Semple BD, Canchola SA, NobleHaeusslein LJ. Deficits in social behavior emerge during development after pediatric traumatic brain injury in mice. $J$ Neurotrauma (2012) 29:2672-83. doi:10. 1089/neu.2012.2595

104. Malkesman O, Scattoni ML, Paredes D, Tragon T, Pearson B, Shaltiel $\mathrm{G}$, et al. The female urine sniffing test: a novel approach for assessing reward-seeking behavior in rodents. Biol Psychiatry (2010) 67:864-71. doi:10.1016/j. biopsych.2009.10.018

105. Gregg B, Thiessen DD. A simple method of olfactory discrimination of urines for the Mongolian gerbil, Meriones unguiculatus. Physiol Behav (1981) 26:1133-6. doi:10.1016/0031-9384(81) 90221-3

106. Luo AH, Cannon EH, Wekesa KS, Lyman RF, Vandenbergh JG, Anholt RR. Impaired olfactory behavior in mice deficient in the alpha subunit of $\mathrm{G}(\mathrm{o})$. Brain Res (2002) 941:62-71. doi:10.1016/ S0006-8993(02)02566-0

107. Agmo A, Pfaff DW. Research on the neurobiology of sexual behavior at the turn of the millennium. Behav Brain Res (1999) 105:1-4.

108. Hull EM, Dominguez JM. Getting his act together: roles of glutamate, nitric oxide, and dopamine in the medial preoptic area. Brain Res (2006) 1126:66-75. doi:10.1016/j. brainres.2006.08.031

109. Martinez-Garcia F, MartinezRicos J, Agustin-Pavon C, Martinez-Hernandez J, Novejarque A, Lanuza E. Refining the dual olfactory hypothesis: pheromone reward and odour experience. Behav Brain Res (2009) 200:277-86. doi:10.1016/j.bbr.2008.10.002

110. Cryan JF, Mombereau C. In search of a depressed mouse: utility of models for studying depressionrelated behavior in genetically modified mice. Mol Psychiatry (2004) 9:326-57. doi:10.1038/sj. mp.4001457

111. Shaltiel G, Maeng S, Malkesman O, Pearson B, Schloesser RJ, Tragon $\mathrm{T}$, et al. Evidence for the involvement of the kainate receptor subunit GluR6 (GRIK2) in mediating behavioral displays related to behavioral symptoms of mania. Mol Psychiatry (2008) 13:858-72. doi:10.1038/mp.2008.20

112. Porsolt RD, Le Pichon M, Jalfre M. Depression: a new animal model sensitive to antidepressant treatments. Nature (1977) 266:730-2. doi:10.1038/266730a0

113. Porsolt RD, Bertin A, Jalfre M. "Behavioural despair" in rats and mice: strain differences and the effects of imipramine. Eur J Pharmacol (1978) 51:291-4. doi:10. 1016/0014-2999(78)90414-4

114. Pare WP. "Behavioral despair" test predicts stress ulcer in WKY rats. Physiol Behav (1989) 46:483-7. doi:10.1016/0031-9384(89) 90025-5

115. Kawashima K, Araki H, Aihara H. Effect of chronic administration of antidepressants on duration of immobility in rats forced to swim. Jpn J Pharmacol (1986) 40:199-204. doi:10.1254/ jjp.40.199

116. Abel EL. Ontogeny of immobility and response to alarm substance in the forced swim test. Physiol Behav (1993) 54:713-6. doi:10. 1016/0031-9384(93)90081-P

117. Porsolt RD, Brossard G, Hautbois C, Roux S. Rodent models of depression: forced swimming and tail suspension behavioral despair tests in rats and mice. Curr Protoc Neurosci (2001) Chapter 8, Unit 8.10A. doi:10.1002/ 0471142301.ns0810as14

118. Hodgson JA. Swimming immobility of REM sleep deprived rats reared in different environments. Physiol Behav (1984) 
32:17-23. doi:10.1016/00319384(84)90063-5

119. Nishimura H, Tsuda A, Oguchi M, Ida Y, Tanaka M. Is immobility of rats in the forced swim test "behavioral despair"? Physiol Behav (1988) 42:93-5. doi:10. 1016/0031-9384(88)90266-1

120. Abel EL, Bilitzke PJ. A possible alarm substance in the forced swimming test. Physiol Behav (1990) 48:233-9. doi:10. 1016/0031-9384(90)90306-O

121. Overstreet DH. The flinders sensitive line rats: a genetic animal model of depression. Neurosci Biobehav Rev (1993) 17:51-68. doi: 10.1016/S0149-7634(05)80230-1

122. Yadid G, Nakash R, Deri I, Tamar G, Kinor N, Gispan I, et al. Elucidation of the neurobiology of depression: insights from a novel genetic animal model. Prog Neurobiol (2000) 62:353-78. doi:10. 1016/S0301-0082(00)00018-6

123. Malkesman O, Braw Y, Maayan R, Weizman A, Overstreet DH, Shabat-Simon M, et al. Two different putative genetic animal models of childhood depression. Biol Psychiatry (2006) 59:17-23. doi: 10.1016/j.biopsych.2005.05.039

124. Lahmame A, Del Arco C, Pazos A, Yritia M, Armario A. Are Wistar-Kyoto rats a genetic animal model of depression resistant to antidepressants? Eur J Pharmacol (1997) 337:115-23. doi:10.1016/ S0014-2999(97)01276-4

125. Lucki I, Dalvi A, Mayorga AJ. Sensitivity to the effects of pharmacologically selective antidepressants in different strains of mice. Psychopharmacology (Berl) (2001) 155:315-22. doi:10.1007/ s002130100694

126. Pollak DD, Rey CE, Monje FJ. Rodent models in depression research: classical strategies and new directions. Ann Med (2010) 42:252-64. doi:10.3109/07853891003769957

127. Pellow S, Chopin P, File SE, Briley M. Validation of open:closed arm entries in an elevated plusmaze as a measure of anxiety in the rat. J Neurosci Methods (1985) 14:149-67. doi:10.1016/ 0165-0270(85)90031-7

128. Dawson GR, Tricklebank MD. Use of the elevated plus maze in the search for novel anxiolytic agents. Trends Pharmacol Sci (1995) 16:33-6. doi:10.1016/ S0165-6147(00)88973-7

129. Blumstein LK, Crawley JN. Further characterization of a simple, automated exploratory model for the anxiolytic effects of benzodiazepines. Pharmacol Biochem Behav (1983) 18:37-40. doi:10. 1016/0091-3057(83)90247-2

130. Cole BJ, Hillmann M, Seidelmann D, Klewer M, Jones GH. Effects of benzodiazepine receptor partial inverse agonists in the elevated plus maze test of anxiety in the rat. Psychopharmacology (Berl) (1995) 121:118-26. doi:10.1007/ BF02245598

131. Shepherd JK, Grewal SS, Fletcher A, Bill DJ, Dourish CT. Behavioural and pharmacological characterisation of the elevated "zeromaze" as an animal model of anxiety. Psychopharmacology (Berl) (1994) 116:56-64. doi:10.1007/ BF02244871

132. Hall CS. Emotional behavior in the rat. I. Defecation and urination as measures of individual differences in emotionality. J Comp Physiol Psychol (1934) 18:385-403. doi:10.1037/h0071444

133. Walsh RN, Cummins RA. The open-field test: a critical review. Psychol Bull (1976) 83:482-504. doi:10.1037/0033-2909.83.3.482

134. Denenberg VH, Garbanati J, Sherman DA, Yutzey DA, Kaplan R. Infantile stimulation induces brain lateralization in rats. Science (1978) 201:1150-2. doi:10.1126/ science. 684436

135. DeFries JC, Hegmann JP, Halcomb RA. Response to 20 generations of selection for openfield activity in mice. Behav Biol (1974) 11:481-95. doi:10.1016/ S0091-6773(74)90800-1

136. Blizard DA, Bailey DW. Genetic correlation between openfield activity and defecation: analysis with the $\mathrm{CXB}$ recombinant-inbred strains. Behav Genet (1979) 9:349-57. doi:10.1007/BF01066973

137. Crawley JN. Behavioral phenotyping of transgenic and knockout mice: experimental design and evaluation of general health, sensory functions, motor abilities, and specific behavioral tests. Brain Res (1999) 835:18-26. doi: 10.1016/S0006-8993(98)01258-X

138. Kessler RC, Stang P, Wittchen HU, Stein M, Walters EE. Lifetime co-morbidities between social phobia and mood disorders in the US National Comorbidity Survey. Psychol Med (1999) 29:555-67. doi:10.1017/ S0033291799008375

139. Christmas AJ, Maxwell DR. A comparison of the effects of some benzodiazepines and other drugs on aggressive and exploratory behaviour in mice and rats. Neuropharmacology (1970) 9:17-29. doi:10. 1016/0028-3908(70)90044-4

140. Stefanski R, Palejko W, Bidzinski A, Kostowski W, Plaznik A. Serotonergic innervation of the hippocampus and nucleus accumbens septi and the anxiolytic-like action of midazolam and 5-HT1A receptor agonists. Neuropharmacology (1993) 32:977-85. doi:10. 1016/0028-3908(93)90063-9

141. Rex A, Voigt JP, Voits M, Fink H. Pharmacological evaluation of a modified open-field test sensitive to anxiolytic drugs. Pharmacol Biochem Behav (1998) 59:677-83. doi:10.1016/S0091-3057(97) 00461-9

142. Calabrese EJ. An assessment of anxiolytic drug screening tests: hormetic dose responses predominate. Crit Rev Toxicol (2008) 38:489-542. doi:10.1080/10408440802014238

143. Crawley J, Goodwin FK. Preliminary report of a simple animal behavior model for the anxiolytic effects of benzodiazepines. Pharmacol Biochem Behav (1980) 13:167-70. doi:10.1016/00913057(80)90067-2

144. Bourin M, Hascoët M. The mouse light/dark box test. Eur J Pharmacol (2003) 463:55-65. doi:10.1016/ S0014-2999(03)01274-3

145. Suzuki T, Lu MS, Motegi $H$, Yoshii T, Misawa M. Genetic differences in the development of physical dependence upon diazepam in Lewis and Fischer 344 inbred rat strains. Pharmacol Biochem Behav (1992) 43:387-93. doi:10. 1016/0091-3057(92)90167-E

146. Einat H. Modelling facets of mania - new directions related to the notion of endophenotypes. $J$ Psychopharmacol (2006) 20:714-22. doi:10.1177/0269881106060241

147. Meyer TD, Hautzinger M. The structure of affective symptoms in a sample of young adults. Compr Psychiatry (2003) 44:110-6. doi:10.1053/comp.2003. 50025

148. Dalhouse AD. Social cohesiveness, hypersexuality and irritability induced by $\mathrm{p}-\mathrm{CPA}$ in the rat. Physiol Behav (1976) 17:679-86. doi 10.1016/0031-9384(76)90169-4

149. Hagan JJ, Jansen JH, Broekkamp CL. Selective behavioural impairment after acute intoxication with trimethyltin (TMT) in rats. Neurotoxicology (1988) 9:53-74.
150. Ferrari F, Tartoni PG, Monti A, Mangiafico V. Does anxiety underly imidazoleinduced behavioural effects in the rat? Psychopharmacology (Berl) (1989) 99:345-51. doi:10.1007/BF00445555

151. Himmelsbach CK, Gerlach GH, Stanton EJ. A method for testing addiction, tolerance and abstinence in the rat: results of its application to several morphine alkaloids. J Pharmacol Exp Ther (1935) 53:179-88.

152. Rasmussen K, Beitner-Johnson DB, Krystal JH, Aghajanian GK, Nestler EJ. Opiate withdrawal and the rat locus coeruleus: behavioral, electrophysiological, and biochemical correlates. J Neurosci (1990) 10:2308-17.

153. Irwin S. Comprehensive observational assessment: Ia. A systematic, quantitative procedure for assessing the behavioral and physiologic state of the mouse. . Psychopharmacologia (1968) 13:222-57. doi: 10.1007/BF00401402

154. Terranova ML, Laviola G, de Acetis L, Alleva E. A description of the ontogeny of mouse agonistic behavior. J Comp Psychol (1998) 112:3-12. doi:10.1037/0735-7036. 112.1.3

155. Blanchard RJ, Wall PM, Blanchard DC. Problems in the study of rodent aggression. Horm Behav (2003) 44:161-70. doi:10.1016/ S0018-506X(03)00127-2

156. Blanchard DC, Blanchard RJ. What can animal aggression research tell us about human aggression? Horm Behav (2003) 44:171-7. doi:10. 1016/S0018-506X(03)00133-8

157. Messeri P, Eleftheriou BE, Oliverio A. Dominance behavior: a phylogenetic analysis in the mouse. Physiol Behav (1975) 14:53-8. doi: 10.1016/0031-9384(75)90141-9

158. Carlier M, Roubertoux PL, Pastoret $\mathrm{C}$. The $\mathrm{Y}$ chromosome effect on intermale aggression in mice depends on the maternal environment. Genetics (1991) 129:231-6.

159. Winslow JT, Miczek KA. Habituation of aggression in mice: pharmacological evidence of catecholaminergic and serotonergic mediation. Psychopharmacology (Berl) (1983) 81:286-91. doi: 10.1007/BF00427564

160. Miczek KA, Maxson SC, Fish EW, Faccidomo S. Aggressive behavioral phenotypes in mice. Behav Brain Res (2001) 125:167-81. doi: 10.1016/S0166-4328(01)00298-4

161. Malkesman O, Pine DS, Tragon T, Austin DR, Henter ID, Chen G, et 
al. Animal models of suicide-traitrelated behaviors. Trends Pharmacol Sci (2009) 30:165-73. doi:10. 1016/j.tips.2009.01.004

162. Lumley LA, Charles RF, Charles RC, Hebert MA, Morton DM, Meyerhoff JL. Effects of social defeat and of diazepam on behavior in a resident-intruder test in male DBA/2 mice. Pharmacol Biochem Behav (2000) 67:433-47. doi:10.1016/S0091-3057(00) 00382-8

163. Adams DB. Defence and territorial behaviour dissociated by hypothalamic lesions in the rat. Nature (1971) 232:573-4. doi:10. $1038 / 232573 \mathrm{a} 0$
164. Potegal M. Temporal and frontal lobe initiation and regulation of the top-down escalation of anger and aggression. Behav Brain Res (2012) 231:386-95. doi:10.1016/j. bbr.2011.10.049

165. Mann JJ, Brent DA, Arango V. The neurobiology and genetics of suicide and attempted suicide: a focus on the serotonergic system. Neuropsychopharmacology (2001) 24:467-77. doi:10. 1016/S0893-133X(00)00228-

166. Brezo J, Paris J, Tremblay R, Vitaro F, Zoccolillo M, Hebert $M$, et al. Personality traits as correlates of suicide attempts and suicidal ideation in young adults. Psychol Med (2006)

36:191-202. doi:10.1017/

S0033291705006719

Conflict of Interest Statement: The authors declare that the research was conducted in the absence of any commercial or financial relationships that could be construed as a potential conflict of interest.

Received: 26 August 2013; paper pending published: 12 September 2013; accepted: 23 September 2013; published online: 07 October 2013.

Citation: Malkesman $\mathrm{O}$, Tucker LB, Oz

$J$ and McCabe JT (2013) Traumatic brain injury - modeling neuropsychiatric symptoms in rodents. Front. Neurol. 4:157. doi: 10.3389/fneur.2013.00157 This article was submitted to Neurotrauma, a section of the journal Frontiers in Neurology.

Copyright (c) 2013 Malkesman, Tucker, $\mathrm{Ozl}$ and McCabe. This is an open-access article distributed under the terms of the Creative Commons Attribution License (CC BY). The use, distribution or reproduction in other forums is permitted, provided the original author(s) or licensor are credited and that the original publication in this journal is cited, in accordance with accepted academic practice. No use, distribution or reproduction is permitted which does not comply with these terms. 